\title{
Tracing the women's movement in India
}

\section{Abstract}

\section{Esheeta Hhanna}

The paper tries to analyze the women's movement in India, it's evolution and the path it covered. It further focuses on the fact if autonomous women organisations can help further in women's movement. The paper tracks the history when women activists participated in the independence movement and later started the activism with the burning question in 70's of rape and later the journey of activism in the movement started. The paper views the role of state where state often is regarded as a tool in the hands of bourgeoisie and blamed for not dealing with women centric issues. It analyses the formation of various organisations and how their development shaped the women's movement in total as a social movement for radical change. It further highlights the limitations of the movement which acted as a barrier in it's success from achieving its goals. The paper concluded by raising other questions which the movement need to address to liberate women from oppression by a patriarchal system in the present times where patriarchy is both practised and turned punitive if not practised.

India, an extremely populous country has a large proportion of world's womenfolk, extreme polarities of social and economic situations, a wide range of political organisations, and a history of political struggle. Women's participation in political life dates back when organisations such as Women's India association and the All India Women's council was formed. The main aim of these organisations formed around 1920's was to eradicate social problems of women. During the national struggle Gandhi used ideological prongs to mobilize women which included commitment to women's equal rights and equal social responsibilities for the Indian struggle and established in constitutional law though discriminations not eliminated. In Tebhaga, women were valiant partners in guerrilla warfare in facing repression. Though they were partners their problems were not articulated in the same way, later the Stree Shakti Sangh members documented the history. Such struggles were initial struggle by women, where at one hand the national movement was coming on an end and on the other women problems not addressed as the need to mobilise was losing its momentum.

To begin with the nineteenth century women movement in India, the need to address this question was seen worldwide. In Europe feminist consciousness began spreading during and after the French Revolution, further taken to England, France and Germany. In Russia woman question became central issue for Russian reformers. In India the reforms began in Maharashtra and Bengal. The activism of the Indian women's movement from early eighties came into a new phase where the most essential thing during this time was focus on a particular issue by the women's movement on 'violence'. Due to varied histories of women activism in India raises certain questions in troubled history of how inclusive was the women's movement or can we see it as a single movement? How do we deal with the deep hierarchies that exist within a movement, and finally a way to address the question of differences that exist in any social movement. To find the starting point of the history of women's movement, to establish this keeping in view the present dimensions certain overlapping and interlinking strands of past to present. Seventies the question of rape became significant for women activists. 
Rape not new in India, for long has been institutionalised form of violence where caste is not to be ignored, as often caste rape is most common and least addressed and gives a view of power relation in society.

Though women's movement claims to be inclusive in nature, one of the accusations levelled against it is that it is largely middle class and urban in its nature, might not be generalised. For instance the one of the few cases that came to light in 1978 was the rape of a muslim poor woman Rameeza Bee where later the political state legislature was forced to give in to the pressure from women's organisation and set an enquiry commission. The only people to focus on the so called women's issue were women's group. Though a quarter century ago state showcased itself to be more responsive to the the issues raised by women's movement, for instance the demand for a change in law was then taken seriously and a law commission was to draft a new legislation, worked with the women's group and legislations placed in the parliament, though when passed it was a watered down version of what the women's group had actually demanded. The women's movement further raised the question of dowry where though there were certain overlapping features as the women's movement led the movement with the question of rape, there were certain marked differences as well. In the initial stages of the movement the activists belived that dowry was limited largely to urban middle class, Hindu India ${ }^{1}$. Later the changing patterns were observed and changes recognized.

\section{The failed State as viewed by the women's Movement}

In both the rape and dowry campaign against sati, the primary target of women's demands or grievances was the state. The assumption was that the state had failed in its 'duty', indeed its promises of women to be safe and free from violence in independent India. That the state itself could be perpetrator of violence, that it could simultaneously speak the language of violence and speak against it at another as the centre, then ruled by a different party from the state, these were realisations that followed later. Anti-sati agitation and the Shahbano case provided the beginnings of another important lesson, which was to become increasingly key over time, that women could be divided by the politics of their religious and caste identity, and that they could be complicit consent to strengthening the structures of patriarchy which worked against them.

While the question of consent and complicity was particularly visible in cases of dowry immolation, it is also possible to locate it in cases of dowry murder. The early years of activism in women's movement were marked by various emerging issues where women as victims was centric to the activism. First, the perception of women as victims of violence and second, the focus on holding the state accountable for the many ways in which such violence manifested itself against women. The activists though highlighted various other issues to bring a positive change in the lives of women. Throughout this time, work continued apace on setting up legal aid centres, taking on case work, organising demonstrations, protest marches, spreading awareness through street plays and responding to the ever increasing range of issues that seemed to be opening up. Nonetheless, whether it was party affiliated groups, those who saw

\footnotetext{
${ }^{I}$ Butania, Urvashi Confrontation and Negotiation:The women's Movement's Responses to violence against Women pp 297
} 
themselves as autonomous/independent, both directed their energies at the state, while at the same time constructing women as victims. To some extent one might even say that the responses of women's groups were fairly straightforward and simple: immediately a case of rape took place, groups would mobilise, lobby for the case to be taken up, demand various things from the government and, if possible, protest marches were quickly organised, and although they were. Later in the process of women's movement where initially activists saw women as victims and men as aggressors, the simplified dichotomy where later women were both actors and victims in the system of patriarchy and established patriarchal norms. Another issue centric to the women's movement foster question of autonomy. As Lenin pointed out "Our ideological conceptions give rise to the principles of organisation no special organisation for women. A woman communist is a member of party that has a male communist with equal right and duties"2. The demand for autonomy and independence of decision making has its historical importance.

What is essential is to view its relationship with border social movements and political currents. Another issue is the fact that there need to be solutions with the emerged problems. For instance if women's exclusive and unrecognised preoccupation with housework is a problem, then how to emerge at a concluding remark to it as often the views among feminists vary ${ }^{3}$.

The 70s also witnessed the emergence of the 'autonomous' women's movement. During the mid-70s, many educated women took to radical, active politics, and simultaneously promoted an analysis of women's issues. Incidents that played catalytic roles in crystallizing these meetings into organizational efforts were the Mathura rape case (1978) and the Maya Tyagi rape case(1980). Both were cases of custodial rape by the police, and led nationwide protest movements by women.

The 70s constituted a watershed in the history of the women's movement in Indian. The analysis of women's operation giving rise to new forma of demand and action noticeable in the Bodhgaya movement was utilised by many other mass movements of this period. These mass movements were a product of the political unrest referred to above, and engulfed entire areas and people despite the Indian state's imposition of the internal emergency in 1975. At the same time, the analysis was taken up by many educated women, and their possible liberation that these groups struggled for, crystallised eventually into what came to be known as the 'autonomous women's movement'.

The decade of 70s also bought women into mass movements in large numbers, although the specific issues and analysis of women's oppression differed from case to case. The Chipko movement in the Gharwal Himalaya dates from the same period as the Bihar movement. The name Chipko is derived from the Hindi word for hugging trees, which is what Garhwal women did en masse in order to prevent indiscriminate forest felling by commercial interests. The issue of environmental degradation was linked in this movement to women's

\footnotetext{
2 Lenin, Mao Tse Tung 'Women and Communism', Calcutta:New book centre,pp105

${ }^{3}$ 3Sen Iliana Feminists, Women's Movement and Working class 377
}

increasing toil for fuel and fodder in the face of such degradation, and from this was generated the idea that women by virtue of their own nature related activities have an especially 
nurturing attitude towards nature. The position was not strictly one arguing for equality, but it did take a women's perspective into account. A very important women's organization to emerge in this period was the Self Employed women's association(SEWA). Originally established in Ahmedabad aa a wing of the textile labour association(TLA), SEWA developed women's cooperatives and credit banks aimed at 'social regeneration and economic uplift among rural women'.

Many of the movements of this period challenged the fundamental tenets $o$ the developmental policy being followed by the state. The Chipko movement, for example, challenged commercial forestry and forest based industrialisation on environmental grounds. At the same time, women specific perspective was developed by the movement as women emerged as the principal activities. In a way these two aspects were closely interrelated, for it was an alternative vision that opened up the possibilities for incorporating women's point of view. The dual character strong statement of alternatives to existing state policy, and its definition/orientation attuned to its women cadres and supporterscharacterised many mass movements during this period. Thus, the Shramik Sangathana of Dhulia challenged the entire model of capital-intensive agricultural development and skewed asset ownership that was emerging in an adivasi area at the same time that it questioned the relevance of traditional tribal personal laws for women In a just society. The Chhattisgarh Mines Shramik Sangh(CMSS) emerged in 1977 as militant trade union in the adivasi belt of Madhya Pradesh². Its activities were directed against the public sector giant attempts to mechanise its operations and research its contractual workers, especially women. it fought for the rights of marginalized manual miners while at the same time challenging the policy of blind mechanization in industry, and upheld women's equal rights to wage labour.

A number of mass movements from this period contributed to an ongoing discussion of the question of women's subordination. By and large, it was generally developed within larger organization. A dialectical process of interaction between these cells and larger organization developed in which the theory and practice of women's question was articulated. The process can be observed in Dhulia, in Chattisgarh, where the Stree Mukti Sangathanaand the Mahila Mukti Morcha developed as separate platforms even though they worked in close conjunction with the larger organization. The Agadhi has taken a strong position on the brutalisation of present day politics which affects women more than any other section of society, and has sought to carve out a separate space for itself to supporting all-women panels of zilla parishad elections. During 70's and 80's urban groups emerged where journals devoted to promoting women's equality came into being in regional languages. These included Feminist Network, Baiza, Ahalya, Pratibadi Chetana, Women's voice ${ }^{3}$.

Many autonomous groups in women organisations led the agitation for reform in rape law and were successful in paving the way for the passage of an amendment which placed the onus of proof of innocence on accused rapist ${ }^{4}$.

In the 80 s, a test case was taken up by the supreme court relating to Shah Bano, a Muslim divorcee, who sought maintenance from her husband under a secular interpretation of the

\footnotetext{
${ }^{2}$ Kumar,R,1989.' Contemporary Indian Feminism' Feminist Review pg 20-22

${ }^{3}$ Sen,I,1989: Feminists, Women's Movement and the Working Class', Economic and Political Weekly 24: pp 163

${ }^{4}$ S.Bastian and R. Siriwardena, 1986: The Women's Question in Asian Exchange, Vol.485,pp 85-87
} 
law of marriage and divorce. Her case received wide support from the press, but the then government bowed to the way of counter-opinion originating in orthodox muslim circles against the interference in their personal affairs and religion. It enacted the muslim personal law bill under which muslim in India would continue to be governed by the personal laws of their religion as laid down in the sharia.

In Hyderabad, the Progressive Women's Organization(PWO) emerged on the Osmania University campus in the early 70s. This group related closely to the radical student and peasant movement in Andhra Pradesh and felt that women's liberation struggles needed a strong base in the struggles of the toiling masses. The PWO took up issues of price rise, dowry, 'eve teasing', sexism in advertisements, etc., and mobilised women students to organize themselves for their own protection and development.

\section{THE QUESTION OF FUNDS NEEDED IN THE WOMEN'S MOVEMENT}

With the inflow of funds and with international cognisance being given to women issue by UN fora, the field of women's activities in India witnessed somewhat unusual growth. The period 1975-85 was officially declared as the UN decade for women, and a large amount of money was channeled into women's activities through various groups and voluntary agencies. These groups undertook a programme of conscientization of organised economic activities for women ${ }^{56}$.

At the same time, the state also adopted in the early 80s-if indeed it did not appropriate much of the rhetoric of the women's movement eg. 'Women will never get their due share until they organize'; 'Women must fight for their own rights' etc. Under state patronage, the National Perspective Plan for women was evolved and systematic plans were formulated for promoting women's education, health status, and political participation. on the eve of 1989 election, the Panchayati Raj bill introduced reservation for women 'panches' at the village level in a bid to empower women. Women and child development were channelled through state established directorates. Through job opportunities thus created I, professional social workers gained status as activists in the cause of women, diluting both concepts of 'activism' and 'organization'.

To conclude with, the review of the women's movement reveal that the vigourous movement has been in existence in India for a long time where if state sponsored women organisations are excluded the important strands include, the women's movement acting in conjunction with mass organisations or political parties; and 'autonomous women's movement.

In autonomous women's movement, the urban women's groups consist of urban intelligentsia and often remained cutoff from mass of the Indian women. However the most vigorously uncompromising of these groups have felt that political parties and mass organisations not committed enough to the women question. Another problem in many of these groups was that as they expanded their sphere of activities either to individual supportive work for women in distress or to research they became dependent on external funds either from the

\footnotetext{
${ }^{5}$ Banerjee Nirmala "Analysing Women's Work Under Patriarchy", From Myths to Markets edited by Sangari Kumkum and Chakravarti Uma (Indian Institute of Advanced Study Shimla, $\left.{ }^{6}\right)$
} 
government or from various foreign agencies. Many mass organisations that had their origin during 70's and 80's have been a key player in introducing women's perspective in totality of the movements. For instance women in Chhattisgarh Mines Shramik Sangh emphasised on women's equal right to work and added a new dimension to working of the entire union.

The communist parties' position on the women question and its evolution history is forked. The reason to this is that though Marxist theoretical position on the women question focused on women's oppression as parallel to and rooted in class oppression. Lenin was vary in introducing feminist issues to working women. Lenin often had revealed distrust of separate women organisations but at the same time he even recognized the need for them. He declared that a woman communist is the member of the party just as man communist. However old attitudes continued to dominate much of the thinking in communist parties.

Vimal Ranadive attacked the self styled Indian feminists by highlighting the distrust of working class movement. Thus unless women fight men for attribution of women's attribution of women's exploitation to patriarchy it is hard to achieve emancipation.

In the women's movement in India many ideological questions are yet to be sorted out, as many of these are still under scrutiny. These include autonomous women's organisation, of relationship between women's movement and a larger class based movement. The important factor though outweighing the many controversy is the positive achievement since independence of an active articulation of women's issues at all levels and many organisational setups. Thus, though there are many limitations and an uneven character of the women's movement since the role of women in the freedom struggle to post independence struggle and later from 70's to the present era, it is this women's movement that began with highlighting the women's issues for first time to raise movement against rapes, dowry, sati and later to bring women to political organisations this movement was radical in fighting against patriarchy then and is continue doing so in the present time till it won't achieve it's final goal of liberating women from the exploitation and oppression from patriarchy and emancipation of a larger women population without a class and caste bias. Thus though the movement is for a radical change the road is still to be travelled to achieve liberation from the present chains which crowd women in social, political and economic sphere. 